\title{
PERANAN SRABI SEBAGAI MAKANAN KHAS UNTUK \\ MEPERTAHANKAN NILAI KEARIFAN LOKAL
}

\author{
Tri Rinawati ${ }^{1}$ \\ Program Studi Manajemen, Fakultas Ekonomi Universitas Semarang \\ rinaoshin@gmail.com \\ Rita Meiriyanti ${ }^{2}$ \\ Program Studi Manajemen, Fakultas Ekonomi Universitas Semarang \\ rita.mey15@gmail.com \\ Diana Puspitasari ${ }^{3}$ \\ Program Studi Akuntansi Fakultas Ekonomi Universitas Semarang \\ dianapuspitasari887@yahoo.com
}

\begin{abstract}
Abstrak
Kearifan lokal tentang makanan tradisional yang terkandung dalam naskah nusantara khususnya naskah Jawa tersebut merupakan warisan nenek moyang yang bernilai tinggi karena dengan mewarisi tradisi tentang makanan, dapat memperkuat identitas dan jati diri bangsa Indonesia secara universal. Penelitian ini menggunakan metode kualitatif dengan pendekatan fenomenologi. Pengumpulan data dilakukan pada observasi (participant observation), wawancara mendalam (in depth interview) dan dokumentasi. Analisis data yaitu data reduction, data display dan conclusion drawing/verification. Uji kredibilitas data dengan triangulasi dan member check. Potensi srabi sebagai makanan khas di Desa Ngampin Ambarawa adalah sebagai sumber pendapatan keluarga. Para pedagang srabi mendapatkan tambahan penghasilan dengan berjualan srabi tersebut. Omzet penjualan akan meningkat pada saat hari libur dan pada saat perayaan tradisi srabinan di bulan Sya'ban yang lebih dikenal dengan "Sya'banan". Upaya pelestarian srabi di Desa Ngampin Ambarawa yaitu dengan terus melestarikan kearifan lokal budaya daerah setempat, misal tradisi Srabinan yang dilaksanakan pada saat bulan Sya'ban terutama pada tanggal 13, 14 dan 15. Peran Pemerintah Daerah setempat (PEMDA) terus melakukan pembinaan pada paguyuban pedagang srabi, agar para pedagang terus dapat mempertahankan keberadaan srabi pada setiap saat. Menjadikan srabi sebagai makanan khas desa Ngampin Ambarawa sebagai upaya untuk mempertahankan nilai kearifan lokal.
\end{abstract}

Kata Kunci : Peranan Srabi, Makanan Khas, Kearifan Lokal

\begin{abstract}
Local wisdom about traditional food contained in the archipelago, especially the Javanese script is a legacy of high-value ancestors because by inheriting the tradition of food, can strengthen the identity and identity of the Indonesian nation universally.This research uses qualitative method with phenomenology approach. Data collection is done on observation (participant observation), in depth interview (in depth interview) and documentation. Data analysis is data reduction, display data and conclusion drawing / verification. Test the credibility of the data with triangulation and member check. The potential of srabi as a typical food in Ngampin Ambarawa Village is as a source of family income. The traders srabi get additional income by selling the srabi. Sales turnover will increase during holidays and during celebrations of the familiar traditions of Sha'ban moon better known as "Sha'banan". Efforts to preserve srabi in the village of Ngampin Ambarawa is by continuing to preserve local wisdom of local culture, eg Srabinan tradition which was held during the month of Sha'ban especially on 13, 14 and 15. The role of local government (PEMDA) continues to provide guidance to the traders of srabi traders, so that traders can continue to maintain the existence of srabi at any time. Making srabi as a special food Ngampin Ambarawa village as an effort to maintain the value of local wisdom.
\end{abstract}

Key Words: The Role of Srabi, Typical Food, Local Wisdom 


\section{PENDAHULUAN}

\section{Latar Belakang Masalah}

Makanan tradisional merupakan fenomena kebudayaan yang semakin di teliti keberadaannya dan semakin ingin mengetahui tentangnya, kebudayaan dapat menentukan makanan sebagai makanan khas suatu daerah. Dengan demikian, makanan bukan sekedar untuk mempertahankan hidup, melainkan juga untuk mempertahankan kebudayaan. (Dewi, 2011).

Sejarah Srabi Ngampin, konon kabarnya, srabi Ngampin sudah ada sejak tahun 1970. Pada hari-hari biasa, yang berdagang serabi ini paling hanya beberapa pedagang saja. Berbeda ketika malam hari dipertengahan bulan Sya'ban, maka banyak berderet penjual srabi di sepanjang jalan Ngampin. Hampir sepanjang jalan terdapat gubuk sederhana tempat menjual srabi. Sejak saat itu semakin banyak yang berjualan bahkan menjadikannya sumber mata pencaharian. Pedagang yang berjualan di bulan Sya'ban hal ini dipercaya para muda-mudi akan didekatkan jodohnya bagi yang belum mendapatkan pasangan atau segera menikah apabila sudah memiliki pasangan setelah memakan srabi Ngampin tersebut. Maka banyak yang mengaitkan nama srabi dengan kata "rabi" yang dalam bahasa jawa artinya menikah. Terlepas dari kepercayaan itu, dengan memakan srabi Ngampin sekaligus menikmatinya, kita telah berkontribusi untuk melestarikan salah satu jajanan tradisional khas Ambarawa.

Kearifan lokal tentang makanan tradisional yang terkandung dalam naskah nusantara khususnya naskah Jawa tersebut merupakan warisan nenek moyang yang bernilai tinggi karena dengan mewarisi tradisi tentang makanan, dapat memperkuat identitas dan jati diri bangsa Indonesia secara universal. Walaupun banyak penambahan variasi makanan dan pola penyajian itu masih dianggap hal yang wajar dan manusiawi. Secara umum makanan tradisional dalam masyarakat nusantara memiliki beberapa fungsi diantaranya untuk menjalin ikatan sosial, kerukunan antar warga, mempererat persaudaraan, termasuk untuk penanaman nilai-nilai spiritual dengan kata lain makanan tradisional memiliki fungsi sosial, fungsi keagamaan (religi), serta fungsi simbolik.

Prospek kearifan lokal sangat bergantung kepada bagaimana masyarakat melestarikan kembali kearifan lokal yang ada dan bagaimana masyarakat mengubah pola pikirnya kembali ke pola pikir holistik. Sehingga sumberdaya alam dan lingkungan yang dimiliki masyarakat dapat dimanfaatkan dan dilestarikan dengan tanpa menganggu keseimbangannya.

Seluruh pemangku kepentingan pemerintahan daerah melestarikan dan merevitalisasi kearifan lokal di Kota Ambarawa sekaligus mendayagunakan potensinya untuk kepentingan kesejahteraan masyarakat, yaitu dengan melakukan upaya pelestarian dan komodifikasi makanan khas Kota Ambarawa melalui (1) Pembinaan dan peningkatan daya saing produk UMKM produsen srabi; (2) Afirmasi dalam pemerintahan tentang sajian makanan khas produk lokal di setiap acara pemerintahan.

Berdasarkan uraian diatas, tim peneliti tertarik untuk melakukan penelitian dengan mengambil judul penelitian "Peranan Srabi Sebagai Makanan Khas Untuk Mempertahankan Nilai Kearifan Lokal”.

\section{Perumusan Masalah}

Merujuk dari latar belakang masalah yaitu upaya mempertahankan kearifan lokal dengan melihat peranan serabi sebagai makanan khas desa Ngampin Ambarawa sehingga muncul perumusan masalah sebagai berikut (1) Bagaimana potensi srabi sebagai makanan khas di Desa Ngampin Ambarawa? (2) Bagaimana upaya pelestarian srabi di Desa Ngampin Ambarawa?. (3) Bagaimana peran PEMDA dalam upaya pelestarian makanan khas srabi Ngampin Ambarawa untuk mempertahankan nilai kearifan lokal?

\section{Batasan Masalah}

Batasan masalah diperlukan agar ruang lingkup penelitian menjadi lebih jelas, fokus dan lebih spesifik. Batasan masalah dalam penelitian ini adalah sumber data dalam penelitian adalah pembeli, pedagang, pejabat setempat atau dinas pasar.

\section{Tinjauan Pustaka \\ Kearifan Loka}

Sibarani (2012) menjelaskan bahwa kearifan lokal adalah kebijaksanaan atau pengetahuan asli suatu masyarakat yang berasal dari nilai luhur tradisi budaya untuk mengatur tatanan kehidupan masyarakat. Kearifan lokal juga dapat didefinisikan sebagai nilai budaya lokal yang dapat dimanfaatkan untuk mengatur tatanan kehidupan masyarakat secara arif atau bijaksana.

Jim Ife (2002) menyatakan bahwa kearifan lokal terdiri dari lima dimensi yaitu (1) Pengetahuan Lokal. 
Pengetahuan lokal terkait dengan perubahan dan siklus iklim kemarau dan penghujan, jenis-jenis fauna dan flora, dan kondisi geografi, demografi, dan sosiografi. Kemampuan adaptasi ini menjadi bagian dari pengetahuan lokal mereka dalam menaklukkan alam. (2) Nilai Lokal. Untuk mengatur kehidupan bersama antara warga masyarakat, maka setiap masyarakat memiliki aturan atau nilai-nilai lokal yang ditaati dan disepakati bersama oleh seluruh anggotannya. (3) Keterampilan Lokal. Kemampuan bertahan hidup (survival) dari setiap masyarakat dapat dipenuhi apabila masyarakat itu memiliki keterampilan lokal. Keterampilan lokal dari yang paling sederhana seperti berburu, meramu, bercocok tanam sampai membuat industri rumah tangga. (4) Sumber daya Lokal. Sumber daya lokal ini pada umumnya adalah sumber daya alam yaitu sumber daya yang tak terbarui dan yang dapat diperbarui. (5) Mekanisme Pengambilan Keputusan Lokal. Menurut ahli adat dan budaya sebenarnya setiap masyarakat itu memiliki pemerintahan lokal sendiri atau disebut pemerintahan kesukuan.

\section{Penelitian Terdahulu}

Penelitian Purwaningsih, Suwarno, Febiola. (2016) menjelaskan bahwa Tradisi nyadran mengandung nilai kearifan lokal hubungan manusia dengan Tuhan, manusia dengan sesamanya, dan manusia dengan lingkungan. Tradisi nyadran yang bertujuan sebagai ungkapan rasa syukur atas nikmat yang diterima, menjadikan manusia selalu ingat kepada Tuhannya. Dalam pelaksanaan tradisi nyadran dapat menjadi penyelaras kebutuhan lahir batin, menjadi perekat sosial lintas agama, etnis, sosial. Tradisi nyadran juga dapat meningkatkan solidaritas, kegotongroyongan, dan guyub rukun.

Penelitian Rahmalianti, Alia, Riyadi (2016) menjelaskan bahwa Penelitian ini menghasilkan kesimpulan yang dihasilkan dari hasil penelitian yang dilakukan oleh peneliti, yaitu sebagai berikut: Masyarakat desa Tarikolot adalah salah satu desa yang mengalami masa sulit dalam hal menemukan beras sebagai sumber karbohidrat. oleh karena itu mereka mengkonsumsi singkong dengan cara dibuat kejos sebagai makanan pokok mereka. Masyarakat desa Tarikolot adalah masyarakat yang bisa dibilang sulit untuk melakukan inovasi. Mereka masih menjungjung tinggi keaslian dari makanan tradisional. Sehingga untuk anak muda zaman sekarang, makanan tradisional kurang diminati. Pemerintah Desa Tarikolot mengupayakan ingin membantu dan ingin melestarikan makanan tradisional yang ada di masyarakat.

\section{Tujuan Penelitian}

Penelitian ini bertujuan : (1) Untuk mengetahui peranan serabi sebagai makanan khas untuk mepertahankan nilai kearifan lokal. (2) Untuk mengetahui upaya-upaya yang akan dilakukan untuk mempertahankan nilai kearifan lokal. (3) Untuk memahami peran Pemerintah Daerah Kabupaten Semarang.

\section{Manfaat Penelitian}

Penelitian ini diharapkan dapat berguna bagi para akademisi di dalam mengembangkan teori manajemen pemasaran. Dan hasil dari penelitian ini dapat diimplikasikan sebagai bahan pertimbangan dalam mempertahankan nilai kearifan lokal.

\section{METODE PENELITIAN}

Penelitian ini menggunakan metode kualitatif dengan sistem kompleksitas, yang diharapkan dapat mengungkap keunikan, proses-proses subyektif dan memahami makna-makna dengan paradigma "fenomenologi". Fenomenologi secara etimologis, berasal dari kata kerja bahasa Yunani, yaitu phanomai yang artinya menunjukkan atau menampakkan diri sendiri dan logos artinya kata, ucapan, ratio, pertimbangan dan bentuk jamaknya adalah phenomena atau gejala yang diartikan sebagai tampilan suatu object, peristiwa kejadian ataupun kondisi-kondisi menurut persepsi (Littlejohn, 2002).

Jadi dengan menggunakan pendekatan fenomenologi, peneliti berusaha untuk menggali peranan srabi sebagai makanan khas untuk mempertahankan nilai-nilai kearifan lokal.

Tate 1

Desin Pecititia

\begin{tabular}{|c|c|}
\hline 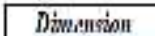 & $F_{\text {plommonhto }}$ \\
\hline Pans & 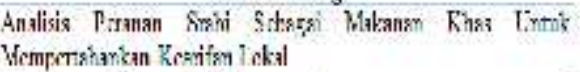 \\
\hline Don Coüntion & Wamancaca, Obserasi. Detarntutas \\
\hline 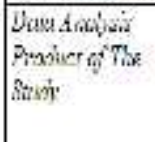 & 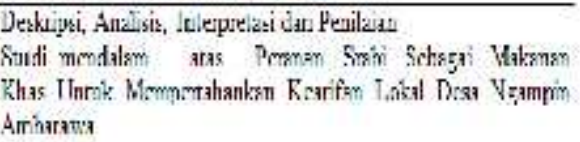 \\
\hline
\end{tabular}

\section{Informan Penelitian}

Dalam penelitian kualitatif yang lebih mengarahkan penelitian pada pengutamaan proses dari pada hasil, yang lebih mementingkan informasi daripada keterwakilan populasi, maka untuk teknik penentuan informan menggunakan purposive dan snowball. Pedagang srabi Ngampin Ambarawa yang 
dijadikan informan dalam penelitian ini diseleksi dengan cara purposive (Creswell, 2007) artinya informan yang dipilih adalah informan sebagai plaku yang mengetahui, mmahami, melakukan serta memiliki data penting yang dibutuhkan peneliti untuk menjawab persoalan-persoalan penelitiandan peranannya yang relevan dengan penelitian ini.

Adapun sumber informasi yang dapat digunakan dalam penelitian ini adalah (a) Sumber data primer, yang dikelompokkan dalam 3 kategori yaitu : Pertama, kelompok pedagang srabi. Kedua, kelompok tokoh masyarakat. Ketiga, masyarakat asli daerah setempat sebagai sumber informasi yang relevan dengan asal usul tradisi dan makanan khas daerah setempat.

\section{Instrumen Penelitian}

Instrumen pendukung pada penelitian ini adalah menggunakan alat perekam suara (MP3 player), kamera digital, serta alat tulis. MP3 player digunakan untuk merekam data lisan saat wawancara, kamera digital untuk mengambil gambar atau foto. Alat tulis digunakan untuk mencatat, cacatan tersebut berupa catatan lapangan.

\section{Teknik Pengumpulan Data}

Sugiyono (2013) menjelaskan bahwa penelitian kualitatif pengumpulan data dilakukan pada natural setting, sumber data primer, dan teknik pengumpulan data lebih banyak pada observasi berperan (participant observation), wawancara mendalam (in depth interview) dan dokumentasi.

\section{Teknik Analisa Data}

Sugiyono (2007) mengemukakan bahwa aktivitas dalam analisis data kualitatif dilakukan secara interaktif dan berlangsung secara terus menerus sampai tuntas, sehingga datanya sudah jenuh. Aktifitas dalam analisis data, yaitu data reduction, data display dan conclusion drawing/verification.

\section{Teknik Keabsahan Data}

Sugiyono (2013) juga mengemukakan beberapa cara untuk melakukan uji kredibilitas data, diantarnya perpanjangan pengamatan, peningkatan ketekunan, triangulasi, diskusi dengan teman, analisis kasus negatif, dan member check.

\section{Model Penelitian}

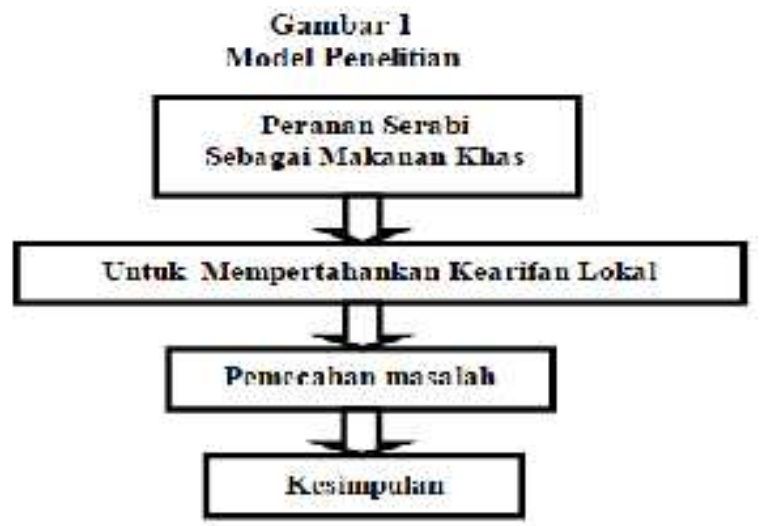

3. HASIL PEMBAHASAN

Profil Komunitas Pedagang Srabi Ngampin Ambarawa

Kuliner Kabupaten Semarang menyajikan berbagai jajanan yang beranekaragam sesuai dengan ciri khas daerah tersebut, salah satunya adalah Srabi Ngampin yang banyak terdapat di Kecamatan Ambarawa. Srabi Ngampin adalah salah satu makanan khas di Ambarawa sejak tahun 1970. Dinamakan srabi Ngampin karena lokasi berjualannya terletak di sepanjang Jl. Raya Ngampin. Jalur antara Semarang dan Yogyakarta.

Pada awalnya srabi Ngampin Ambarawa tidak menggunakan kuah, berbeda dengan srabi Ngampin yang sekarang. Menurut sumber informasi yaitu Ibu Arminah berusia sekitar 75 tahun yang mempunyai dua orang anak yang betempat tinggal di Lingkungan Seneng, Ibu Arminah selaku sesepuh pedagang srabi Ngampin Ambarawa menjelaskan kepada peneliti :

"Pada awalnya srabi dibuat dari beras dan kelapa yang ditumbuk secara bersama-sama sampai halus, kemudian di jer atau diberi air, baru kemudian dimasak di wajan kecil dari tanah liat yang dimasak diatas anglo (kompor dari tanah liat), bara apinya dari arang. Ketika ada pembeli maka srabi tinggal dibungkus saja dengan daun tanpa menggunakan kuah seperti sekarang. Pada jaman dulu, Srabi hanya ada di tradisi Sya'banan di bulan Ruwah tanggal 15”.

Dengan berjalannya waktu, karena dirasa merepotkan dalam memasaknya, maka untuk membuat srabi, beras tinggal di slep atau dihaluskan menjadi tepung kemudian kelapanya diparut untuk dibuat santan. Penyajian srabi sekarang dengan kuah atau "juroh" yang terbuat dari gula merah, pandan dan santan yang direbus. Untuk memasak srabi Ngampin masih sama dengan menggunakan anglo dan cetakan tradisional terbuat dari tanah liat tanpa minyak, apinya pun masih pakai kayu bakar, jadi bakal ada bekas 
bintik bintik seperti pasir di bagian bawahnya. Bentuk srabinya mungil, pada awalnya srabi hanya ada 2 warna, putih yang tawar dan coklat dari gula merah, namun kini srabi ada satu warna lagi yaitu hijau dari daun suji atau pandan.

Menurut penuturan ibu Suparni, salah satu pedagang srabi, menjelaskan kepada peneliti :

"Dengan berjualan srabi dapat membantu peningkatan ekonomi keluarga terutama untuk memenuhi kebutuhan sehari-hari dalam mencukupi kebutuhan keluarga. Setiap hari yang berjualan srabi di sepanjang jalan raya Ngampin sekitar 25 sampai 40 pedagang, sedangkan di hari minggu dapat meningkat hingga 45 sampai 70 pedagang. Pada saat bulan Sya'ban atau saat tradisi srabinan lebih meningkat hingga sampai ratusan pedagang. Omset penjualan para pedagang pada harihari biasa antara 3/4 - $1 \mathrm{~kg}$ tepung beras setiap hari, hari minggu sekitar 1-3 kg tepung beras dan pada saat tradisi srabinan dapat meningkat drastis hingga 5-8 kg tepung beras, sedangkan pada hari Raya Idul Fitri selama satu minggu omset penjualan antara 3-5 kg tepung beras. Dengan demikian pedagang srabi di Kelurahan Ngampin dapat meningkatkan penghasilannya, sehingga kesejahteraannyapun turut meningkat terutama dirasakan pada saat upacara tradisi srabinan berlangsung”.

Untuk menjaga eksistensi dan menyelaraskan kepentingan, puluhan pedagang srabi di Desa Ngampin itu dibentuklah Paguyuban Srabi. Lewat paguyuban itu para pedagang dapat mengatur produksi juga membuat sistem pembiayaan simpan pinjam khusus untuk anggota. Berangkat dari kepentingan ekonomi yang sama, pedagang srabi di Desa Ngampin, Kecamatan Ambarawa, sepakat membentuk organisasi bernama Paguyuban Srabi.

Ada 78 pedagang srabi yang bergabung menjadi anggota paguyuban. Selain menjadi tempat bermusyawarah tentang penjualan srabi, paguyuban juga menjadi ajang pengikat rasa kekeluargaan antar pedagang. Tidak semua pedagang serabi ikut bergabung menjadi anggota. Pihak paguyuban pun tidak keberatan karena tidak ada paksaan menjadi anggota.

Menurut Ibu Sutarti berusia sekitar 46 tahun, beliau selaku penggerak paguyuban, sekaligus sebagai pencetus nama paguyuban "Mekar Lestari" menjelaskan kepada peneliti :

"Pada tahun 1988, pedagang serabi semula berjumlah dua orang yang bernama Ibu Rusmi dan Ibu Suliyem, beliau sudah almarhumah.
Kemudian pedagang bertambah menjadi lima orang yaitu Ibu Karsini, Ibu Romlah, Ibu Arminah, Ibu Semi dan seterusnya terus bertambah jumlah pedagang srabi, karena dirasa semakin laris.

Semakin banyaknya pedagang srabi maka akan dibentuklah paguyuban. Pedagang-pedagang srabi tersebut diberikan pembinaan dari kecamatan dan kabupaten. Pertama kali yang memberikan pembinaan adalah dari Ibu HWK (Ibu Wanita Karya) dari organisasi Golongan Karya. Kemudian dibentuklah organisasi paguyuban pedagang srabi Ngampin.

Paguyuban pedagang srabi semula beranggotakan 23 orang tahun 1998. Pembinaan berikutnya adalah dari APBD dan DISPERINDAG dengan janji akan dibuatkan Koperasi dengan nama Mekar Lestari. Sedangkan organisasi pedagang srabi tersebut namanya hanya "Paguyuban Srabi Ngampin". Dan akhirnya berkembangnya organisasi tersebut maka Ibu Sutarti selaku ketua paguyuban, memberikan nama paguyuban tersebut dengan nama "Mekar Lestari".

Pada tahun 2007, Ibu Sutarti mengundurkan diri dari paguyuban pedagang srabi Ngampin dikarenakan diterima sebagai Pegawai Negeri Sipil untuk mengajar di Sekolah Taman Kanak-kanak. Sebagai pengganti ketua paguyuban, maka dipilihlah ibu Romyati yang menjabat sampai dengan sekarang.

Tinhel.5.I.

\begin{tabular}{|c|c|}
\hline Namia & Iahatan \\
\hline Fonnyali & Ficture \\
\hline Siti Suryatinsh & Sielcretaris 1 \\
\hline $\begin{array}{l}\text { FrisLy und AstuL (TeL) } \\
\text { Pawiti }\end{array}$ & Sclarctaris 2 \\
\hline $\begin{array}{l}\text { Siti Sury ativath } \\
\text { Ponirah }\end{array}$ & $\begin{array}{l}\text { Sirsial Arisan } \\
\text { Susial }\end{array}$ \\
\hline $\begin{array}{l}\text { Kristyanti Astut (1et) } \\
\text { Romyati }\end{array}$ & $\begin{array}{l}\text { Talbumgan wajjil } \\
\text { Talmumgan wajil }\end{array}$ \\
\hline
\end{tabular}

Ibu Romiyati selaku ketua Paguyuban Srabi Mekar Lestari menjelaskan kepada peneliti :

"Salah satu fungsi paguyuban adalah membuat aturan berdagang srabi di sepanjang jalan raya Desa Ngampin. Untuk mengambil keputusan, anggota paguyuban menerapkan asas kekeluargaan dan musyawarah untuk mufakat. Keputusan yang sudah diputuskan, harus ditaati seluruh anggota paguyuban. Contoh, keputusan pembatan produksi srabi untuk setiap pedagang. Keputusan itu harus dipatuhi anggota. Selain mencegah kelebihan produksi, aturan itu untuk mencegah terjadi monopoli penjualan srabi pada beberapa pedagang srabi." 
Menurut Ibu Romiyati, pembatasan produksi itu membuat pedagang serabi punya kesempatan sama dalam meraih keuntungan. Jika ada pedagang yang telah habis menjajakan srabinya, maka ia wajib pulang dan tidak boleh menambah produksi lagi. Adanya pengaturan produksi itulah yang membuat tertarik pedagang srabi bergabung dalam paguyuban. Aturan pembatasan produksi tidak diberlakukan saat musim Lebaran atau saat permintaan srabi naik drastis.

Paguyuban juga memiliki pertemuan rutin bulanan, yang diselenggarakan setiap tanggal 6 . Dalam pertemuan itu, setiap anggota mengumpulkan iuran wajib senilai Rp 2.000 per bulan, iuran sosial Rp 2.000 per bulan, tabungan sukarela sesuai kemampuan. Ketika anggota membutuhkan dana, mereka bisa meminjam uang kas paguyuban sampai dengan Rp 2 juta tanpa harus bayar bunga. Bersumber dari iuran anggota itulah paguyuban mampu menyimpan kas hingga Rp 30 juta. Dana kas tersebut sepenuhnya dimanfaatkan untuk kepentingan anggota.

\section{Peranan Srabi sebagai makanan khas Untuk Mempertahankan Kearifan Lokal}

Kearifan lokal adalah bagian dari budaya Jawa yang merupakan bagian dari budaya Jawa yang memiliki pandangan hidup tertentu tentang hidup manusia yang akan memancarkan ratusan dan bahkan ribuan kearifan lokal.

Adapun kearifan lokal merupakan fenomena yang luas dan komprehensif serta merupakan cakupan kearifan lokal yang cukup banyak dan beragam sehingga sulit dibatasi oleh ruang. Kearifan tradisional dan kearifan kini berbeda dengan kearifan lokal. Kearifan lokal lebih menekankan pada tempat dan lokalitas dari kearifan tersebut sehingga tidak harus merupakan sebuah kearifan yang telah diwariskan dari generasi ke generasi. Kearifan lokal bisa merupakan kearifan yang belum lama muncul dalam suatu komunitas sebagai hasil dari interaksinya dengan lingkungan alam dan interaksinya dengan masyarakat serta budaya lain. Oleh karena itu, kearifan lokal tidak selalu bersifat tradisional karena dia dapat mencakup kearifan masa kini dan karena itu pula lebih luas maknanya daripada kearifan tradisional.

Kearifan lokal adalah dasar untuk pengambilan kebijakan pengelolaan sumber daya alam dan kegiatan masyarakat pedesaan. Dalam kearifan lokal, terkandung pula kearifan budaya lokal, sedangkan kearifan budaya lokal sendiri adalah pengetahuan lokal yang sudah sedemikian menyatu dengan sistem kepercayaan, norma, dan budaya serta diekspresikan dalam tradisi dan mitos yang dianut dalam jangka waktu lama.

Sartini (2004) menjelaskan local berarti setempat, sedangkan wisdom (kearifan) sama dengan kebijaksanaan. Secara umum maka local wisdom (kearifan setempat) dapat dipahami sebagai gagasangagasan setempat (lokal) yang bersifat bijaksana, penuh kearifan, bernilai baik, yang tertanam dan diikuti oleh anggota masyarakatnya. Adapun menurut Ridwan (2007), kearifan lokal atau sering disebut local wisdom dapat dipahami sebagai usaha manusia dengan menggunakan akal budinya (kognisi) untuk bertindak dan bersikap terhadap sesuatu, objek, atau peristiwa yang terjadi dalam ruang tertentu. Pengertian di atas, disusun secara etimologi, di mana wisdom dipahami sebagai kemampuan seseorang dalam menggunakan akal pikirannya dalam bertindak atau bersikap sebagai hasil penilaian terhadap sesuatu, objek, atau peristiwa yang terjadi.

Makna yang terkandung dari cerita tersebut adalah bahwa untuk mencapai tujuan yang diinginkan, seseorang harus mensucikan hati dan jiwanya dengan tulus, berharap kepada Tuhan agar maksud mulia tersebut bisa terkabul dan tradisi serta ritual Sya'banan ini masih dilakukan setiap tahunnya, terutama pada tanggal ke 13, 14, dan 15 di Bulan Sya'ban.

Cerita Sya'banan yang berkembang di Kecamatan Ambarawa. Sampai saat ini masyarakat sekitar sendang maupun sungai di tujuh mata air tersebut diatas selalu menjaga dan merawatnya. Setiap saat masyarakat sekitar selalu menggunakan air di sendang maupun sungai tersebut untuk kebutuhan sehari-hari, baik untuk mandi, mencuci, maupun untuk kebutuhan ternaknya. Setiap tahunnya masyarakat selalu mengadakan ritual adat dengan cara mengeluarkan sedekah berupa uncetan atau dalam bahasa jawa bancaan dan doa bersama kepada Tuhan Yang Maha Kuasa dan dilanjutkan dengan membersihkan sendang dengan dikuras. Kegiatan ini telah menjadi bagian dari upaya menjaga kearifan lokal budaya yang ada Kabupaten Semarang. Adapun kue Srabi, kini telah menjadi sumber kehidupan sebagian masyarakat Ngampin Ambarawa dan menjadi kuliner khas yang dapat diperoleh setiap saat.

\section{Konsep Pemberdayaan Berbasis Kearifan Lokal}

Sutoro (2002) mendefinisikan pemberdayaan sebagai proses mengembangkan, memandirikan, menswadayakan dan memperkuat posisi tawar menawar masyarakat lapisan bawah terhadap kekuatan-kekuatan penekan di segala bidang dan sektor kehidupan. 
Sutoro (2002) juga menjelaskan bahwa konsep pemberdayaan dapat dipahami juga dengan dua cara pandang, (1) pemberdayaan dimaknai dalam konteks menempatkan posisi berdiri dari masyarakat. Posisi masyarakat bukanlah obyek penerima manfaat yang tergantung pada pemberian dari pihak luar seperti pemerintah, melainkan dalam posisi sebagai subyek yang berbuat secara mandiri. Berbuat secara mandiri bukan berarti lepas dari tanggungjawab pemerintah. (2) Pemberian layanan publik kepada masyarakat tentu merupakan tugas pemerintah. Masyarakat yang mandiri sebagai partisipan berarti terbukanya ruang dan kapasitas mengembangkan potensi kreasi, mengontrol lingkungan dan sumberdayanya sendiri..

Tujuan pemberdayaan masyarakat adalah memampukan dan memandirikan masyarakat terutama dari kemiskinan dan keterbelakangan. Kemiskinan dapat dilihat dari indikator pemenuhan kebutuhan dasar yang belum mencukupi atau layak. Kebutuhan dasar itu, mencakup pangan, pakaian, papan, kesehatan, pendidikan, dan transportasi. Sedangkan keterbelakangan, misalnya produktivitas yang rendah, sumberdaya manusia yang lemah, terbatasnya akses pada tanah padahal ketergantungan pada sektor pertanian masih sangat kuat, melemahnya pasar-pasar lokal atau tradisional. Dengan perkataan lain masalah keterbelakangan menyangkut struktural (kebijakan) dan kultural (Usman, 2004).

Pemberdayaan masyarakat berbasis kearifan lokal yaitu dengan memperkuat nilai-nilai dan norma-norma leluhur dari nenek moyang yang ada di masyarakat agar terjaga utuh kearifan lokal, mempertahankan budaya yang ada di masyarakat dengan bertindak secara rasional.

\section{KESIMPULAN}

(1) Kearifan lokal adalah dasar untuk pengambilan kebijakan pengelolaan sumber daya alam dan kegiatan masyarakat pedesaan. Dalam kearifan lokal, terkandung pula kearifan budaya lokal, sedangkan kearifan budaya lokal sendiri adalah pengetahuan lokal yang sudah sedemikian menyatu dengan sistem kepercayaan, norma, dan budaya serta diekspresikan dalam tradisi dan mitos yang dianut dalam jangka waktu lama.

(2) Pemberdayaan masyarakat berbasis kearifan lokal yaitu dengan memperkuat nilai-nilai dan norma-norma leluhur dari nenek moyang yang ada di masyarakat agar terjaga utuh kearifan lokal, mempertahankan budaya yang ada di masyarakat dengan bertindak secara rasional.
(3) Potensi srabi sebagai makanan khas di Desa Ngampin Ambarawa adalah sebagai sumber pendapatan keluarga. Para pedagang srabi mendapatkan tambahan penghasilan dengan berjualan srabi tersebut. Omzet penjualan akan meningkat pada saat hari libur dan pada saat perayaan tradisi srabinan di bulan Sya'ban yang lebih dikenal dengan "Sya'banan".

(4) Cerita Sya'banan yang berkembang di Kecamatan Ambarawa. Sampai saat ini masyarakat sekitar sendang maupun sungai di tujuh mata air tersebut diatas selalu menjaga dan merawatnya. Setiap saat masyarakat sekitar selalu menggunakan air di sendang maupun sungai tersebut untuk kebutuhan sehari-hari, baik untuk mandi, mencuci, maupun untuk kebutuhan ternaknya. Setiap tahunnya masyarakat selalu mengadakan ritual adat dengan cara mengeluarkan sedekah berupa uncetan atau dalam bahasa jawa bancaan dan doa bersama kepada Tuhan Yang Maha Kuasa dan dilanjutkan dengan membersihkan sendang dengan dikuras. Kegiatan ini telah menjadi bagian dari upaya menjaga kearifan lokal budaya yang ada Kabupaten Semarang. Adapun kue Srabi, kini telah menjadi sumber kehidupan sebagian masyarakat Ngampin Ambarawa dan menjadi kuliner khas yang dapat diperoleh setiap saat.

(5) Upaya pelestarian srabi di Desa Ngampin Ambarawa yaitu dengan terus melestarikan kearifan lokal budaya daerah setempat, misal tradisi Srabinan yang dilaksanakan pada saat bulan Sya'ban terutama pada tanggal 13, 14 dan 15. Dalam menjaga dan mempertahankan kearifan lokal, baik pemerintah maupun masyarakat harus memiliki peran.

I. Peran Pemerintah, (a) Pemerintah harus lebih memperkenalkan dan mempromosikan kebudayaan-kebudayaan Indonesia ke daerah-daerah lain lewat iklan atau media cetak (b) Membuat acara pergelaran kebudayaan Indonesia di daerah sendiri atau di daerah lain. (c) Memberikan hak paten terhadap setiap kebudayaan yang dimiliki setiap daerah, seperti lagu daerah, tarian, alat musik dan makanan khas. (d) Memperkenalkan dan mempromosikan ke daerah lain. (e) Membuat pameran - pameran produk Indonesia

II. Peran Masyarakat (a) Melestarikan dan mengembangkan budaya daerah. 
Dinamika Sosial Budaya, Vol 19, No. 2, Desember 2017, pp 300-307

p-ISSN: 1410-9859\& e-ISSN: 2580-8524

http://journals.usm.ac.id/index.php/jdsb

Mencintai produk daerah. (c) Saling menghormati dan menghargai sesama masyarakat. (d) Bersama-sama pemerintah mengembangkan dan memajukan kebudayaan-kebudayaan daerah.

\section{Saran}

Penelitian mendatang diharapkan dapat menggunakan populasi di tingkat Kabupaten agar mendapatkan informan yang lebih luas.

\section{Ucapan Terima Kasih}

Penulis menyampaikan terima kasih kepada Lembaga Penelitian dan Pengabdian Kepada Masyarakat (LPPM) atas biaya penelitian.

\section{DAFTAR PUSTAKA}

Arikunto S, 2006. Prosedur Penelitian Suatu Pendekatan Praktik, Ed Revisi VI, Penerbit PT Rineka Cipta, Jakarta

Dewi, Kumala. (2011). Kearifan Lokal makanan tradisional Rekonstruksi Naskah Jawad an fungsinya dalam masyarakat. Vol:1,No:1

Djam'an Satori, dkk. (2007). Profesi Keguruan. Jakarta: Universitas Terbuka

Eko, Sutoro. 2002, Pemberdayaan Masyarakat Desa, Materi Diklat Pemberdayaan Masyarakat Desa, yang diselenggarakan Badan Diklat Provinsi Kaltim, Samarinda, Desember 2002.

Jim Ife. (2002). Community Development: Community Based alternative in an Age of globalization. Australia: Parson education

Kusumaningtyas, Wibisono, Kusnadi. 2013. Penggunaan Istilah Makanan Dan Jajanan Tradisional Pada Masyarakat Di Kabupaten Banyuwangi Sebuah Kajian. Publika Budaya. Vol 1 (1) 2013.Hal 1-9

Kuswarno, Engkus. , 2009. Metode Penelitian Komunikasi : Fenomenologi, Konsepsi, Pedoman dan Contoh Penelitiannya, Widya Padjajaran, Perpustakaan Pusat UII

Maharani, Y. (2011). "Pelestarian budaya indonesia melalui pembangunan fasilitas pusat jajanan tradisional jawa barat". Ilmu Perpustakaan Universitas Islam Negri Hidayatullah Jakarta. Jakarta: Tidak diterbitkan

Moleong L J. (2007). Metodologi Penelitian Kualitatif. Penerbit PT Remaja Rosdakarya Offset. Bandung

Nasiwan, dkk. 2012. Dari Kampus UNY untuk Indonesia Baru. Yogyakarta: Penerbit ARTI

Purwaningsih, Suwarno, Febiola. (2016). Kearifan Lokal Dalam Tradisi Nyadran Masyarakat Sekitar Situs Liangan. ISBN : 978-979-897163-1.

Rahmalianti, Alia, Riyadi. 2016. Pelestarian Makanan Tradisional Kejos Sebagai Sumber Karbohidrat Di Desa Tarikolot Kecamatan
Jatinunggal Kabupaten Sumedang Provinsi Jawa Barat. Vol (3). No (1). 2016

Ridwan, N. A. (2007). Landasan Keilmuan Kearifan Lokal. Ibda P3M STAIN Purwokerto Vol 5 No.1 , 27-38.

Sartini. (2004). Menggali Kearifan Lokal Nusantara Sebuah Kajian Filsafati. Jurnal Filsafat Jilid 37, Nomor $2,111$.

Sibarani, Robert 2012. Kearifan Lokal: Hakikat, Peran dan Metode Tradisi Lisan. Jakarta: Asosiasi Tradisi Lisan

Sugiyono. (2007). Metode Penelitian Bisnis (Pendekatan Kuantitatif, Kualitatif, dan $R \& D)$. Bandung: Alfabeta.

Sugiono, 2013. Metodologi Penelitian Kualitatif \& RND. Bandung. Alfabeta.

Usman Sunyoto. 2004. "Pembangunan dan Pemberdayaan Masyarakat", Yogyakarta, Pustaka Pelajar 